\title{
SINTESIS NANOPARTIKEL PERAK DAN PENGARUH PENAMBAHAN ASAM $p$-KUMARAT UNTUK APLIKASI DETEKSI MELAMIN
}

\section{Synthesis of Silver Nanoparticles and The Effect of $p$-Coumaric Acid for Detecting Melamine}

\author{
Irwan R ${ }^{1 *}$, Muhammad Zakir ${ }^{2}$, Prastawa Budi ${ }^{2}$ \\ ${ }^{1}$ Pharmacy Program, Department of Health, Polytechnic of Baubau \\ Jl. Lakarambau, Baubau 93721 \\ ${ }^{2}$ Departement of Chemistry, Faculty of Science, Hasanuddin University \\ Jl. Perintis Kemerdekaan, Makassar 90245
}

*Corresponding author, e-mail: irwan07kimia@gmail.com

Received: Oct. 2019 Published: Jan. 2020

\begin{abstract}
Biosynthesis of silver nanoparticles (AgNPs) using mangosteen bark extract, modification and its application in detecting melamine has conducted. This research aimed to synthesize AgNPs via bio-reduction method using mangosteen bark extract followed by modification with p-coumaric acid (APK), and evaluating its application detecting melamine. The AgNPs were characterized through ultraviolet-visible absorption spectroscopy (UV-Vis), Fourier transform infrared absorption spectroscopy (FTIR), and X-ray diffraction (XRD). Observation suggested that an increase of incubation time had affected its surface Plasmon resonance trend. Observation of functional group by FTIR showed that carbonyl group $\left(1707 \mathrm{~cm}^{-1}\right)$ suspected from hydroxyl group $\left(3414 \mathrm{~cm}^{-1}\right)$. Further analysis of crystallite via XRD suggested that nanoparticle size at $30 \mathrm{~nm}$ estimated using Debye-Scherer, within the form of unit cells is cubic. Modified AgNPs showed an interaction between APK and particle surface through $\mathrm{C}=\mathrm{C}$ alkenes $\left(1598 \mathrm{~cm}^{-1}\right)$ and aromatics $\left(1672 \mathrm{~cm}^{-1}\right),=\mathrm{C}-\mathrm{H}$ aromatic $\left(3070 \mathrm{~cm}^{-1}\right)$, aliphatic $\mathrm{C}-\mathrm{H}\left(2501 \mathrm{~cm}^{-1}\right), \mathrm{C}-\mathrm{O}$ $\left(1107 \mathrm{~cm}^{-1}\right)$ and $\mathrm{C}=\mathrm{O}$ carboxylate $\left(1774 \mathrm{~cm}^{-1}\right)$. The performance of product as melamine detector suggested that the AgNPs-APK had detected melamine in range of concentration from 0.1 to $1000 \mathrm{ppm}$.
\end{abstract}

Keywords: Silver nanoparticles, surface plasmon resonance, mangosteen, p-coumaric acid, melamine.

\section{PENDAHULUAN}

Melamin merupakan senyawa dengan struktur molekul 1,3,5-triazina-2,4,6-triamina, digunakan dalam industri resin sebagai pencegah panas. Melamin mengandung 66\% nitrogen dari total massanya sehingga beberapa kasus dilaporkan bahwa melamin secara ilegal ditambahkan ke dalam produk susu dan makanan. Pada tahun 2008, pemalsuan produk susu formula bayi dengan menggunakan melamin di China menyebabkan ribuan bayi mengalami muntahmuntah (Qiao dkk., 2010).

Berbagai metode analisis melamin cukup berkembang seperti metode high performance liquid chromatography (HPLC) (Venkatasami dan Sowa, 2010), gas chromatography-mass spectrometry (GC-MS) (Squadrone dkk., 2010). Metode analisis melamin secara HPLC dan GCMS merupakan metode analisis yang akurat.
Namun, metode ini membutuhkan instrumen yang mahal dan memerlukan waktu yang relatif lama dalam mengidentifikasi melamin. Teknik alternatif dibutuhkan untuk mendeteksi melamin. Salah satu metode yang dapat digunakan adalah dengan memanfaatkan nanopartikel untuk mendeteksi melamin secara kolorimetri.

Nanopartikel sebagai sensor melamin merupakan hal yang menarik perhatian peneliti. Penggunaan nanopartikel seperti nanopartikel perak dan emas menyediakan hasil relatif cepat, akurat dan murah dalam mendeteksi keberadaan melamin dalam produk makanan (Chen dkk., 2015, Han dan Li, 2010, Liang dkk., 2011, Ping dkk., 2012, Song dkk., 2014, Wu dkk., 2011). Adanya senyawa yang bertindak sebagai stabilisator memungkinkan terjadi interaksi dengan melamin. Interaksi nanopartikel dengan melamin dapat melalui interaksi donor-akseptor 
(Han dan Li, 2010), ikatan hidrogen (Jean dkk., 2010) dan secara elektrostatik (Ma dkk., 2011).

Penggunaan senyawa organik dalam modifikasi nanopartikel untuk deteksi melamin menunjukkan tingkat deteksi yang relatif lebih sensitif. Penelitian yang dilakukan Huang dkk. (2011a) melaporkan perbandingan AgNP termodifikasi dan tidak termodifikasi menghasilkan nilai deteksi melamin masingmasing sebesar 46,5 nM dan 41,7 nM. Beberapa senyawa organik digunakan dalam modifikasi nanopartikel untuk deteksi melamin seperti asam kromatropik-AgNP (Song dkk., 2014), pirocatecol-3,5-disodiumsulfonat-AuNP $\quad(\mathrm{Wu}$ dkk., 2011), sisteamin-AuNP (Liang dkk., 2011), sitrat-AgNP (Ping dkk., 2012), p-nitroanilinAgNP (Han dan Li, 2010), dopamin-AgNP (Ma dkk., 2011), crown eter-AuNP (Kuang dkk., 2011)

Penelitian tentang sintesis AgNP dengan prekursor senyawa $\mathrm{AgNO}_{3}$ melalui reduksi ion logam $\mathrm{Ag}^{+}$menjadi $\mathrm{Ag}^{0}$ menggunakan ekstrak tumbuhan berkembang cukup pesat. Kandungan senyawa seperti flavonoid dalam ekstrak buah Syzygium cumini dapat mereduksi logam $\mathrm{Ag}^{+}$ menjadi $\mathrm{Ag}^{0}$ (Mittal dkk., 2014). Senyawa tannin yang terdapat dalam ekstrak daun Terminalia cattapa (Zakir dkk., 2014), gula pereduksi dan flavonoid pada Cacumen platycaldi (Huang dkk., 2011b), senyawa flavonoid, terpen dan fenol pada kulit kayu Ficus benghalensis dan Azadirachta indica (Nayak dkk., 2016) dilaporkan mampu mereduksi senyawa $\mathrm{AgNO}_{3}$ menjadi partikel AgNP. Nanopartikel perak yang disintesis menggunakan ekstrak daun Syzygium polyanthum dilaporkan memiliki aktivitas antioksidan (Taba dkk., 2019). Pemanfaatan tumbuhan sebagai agen pereduksi logam memberikan suatu metode yang sederhana, ramah lingkungan dan relatif murah (Niraimathi dkk., 2012, Yousefzadi dkk., 2014).

Jenis tanaman yang cukup potensial sebagai bioreduktor dalam sintesis AgNP adalah kulit buah manggis (Rajakanu dkk., 2015). Senyawa metabolit sekunder seperti $\alpha$-mangostin, $\beta$ mangostin, $\gamma$-mangostin, garcinone $\mathrm{E}, \quad 8$ deoksigartanin, dan gartanin (Chaverri dkk., 2008) dalam tanaman manggis mengindikasikan tanaman ini cukup potensial sebagai senyawa reduktor dalam sintesis AgNP. Senyawa $\alpha$ mangostin, $\beta$-mangostin, $\gamma$-mangostin berpotensi sebagai inhibitor $\alpha$-amilase pangkreas manusia (Gaspersz dan Sohilait, 2019). Penelitian yang dilakukan Tikirik (2015) menunjukkan bahwa koloid AgNP yang disintesis menggunakan ekstrak kulit buah manggis berpotensi sebagai indikator keberadaan logam $\mathrm{Hg}^{2+}$.

Modifikasi AgNP hasil bioreduksi menggunakan ekstrak kulit buah manggis perlu dilakukan untuk meningkatkan selektivitas AgNP terhadap sensor melamin secara kolorimetri (Huang dkk., 2011a). Salah satu senyawa yang berpotensi digunakan untuk modifikasi adalah senyawa asam $p$-kumarat $\left(\mathrm{C}_{9} \mathrm{H}_{8} \mathrm{O}_{3}\right)$. Senyawa $\mathrm{C}_{9} \mathrm{H}_{8} \mathrm{O}_{3}$ memiliki gugus karbonil, hidroksil dan $\alpha$ hidroksi fenol yang berpotensi berinteraksi dengan AgNP dan melamin. Penelitian Song dkk. (2014) melaporkan bahwa modifikasi asam kromatropik pada permukaan AgNP melalui gugus hidroksil yang menandai keberhasilan modifikasi AgNP. Oleh karena itu, penelitian sintesis AgNP menggunakan ekstrak kulit buah manggis serta modifikasi material AgNP dengan asam $p$-kumarat telah dilakukan dan digunakan dalam deteksi melamin secara kolorimetri.

\section{METODOLOGI}

\section{Alat}

Alat yang diperlukan dalam penelitian ini adalah alat gelas yang umum dalam laboratorium, oven (Gen Lab), neraca analitik (OHAUS), spektrofotometer UV-Vis (UV-2600), X-ray diffraction (Shimadzu 7000), spektrofotometer Fourier Transform Infrared (IRPrestige-21), centrifuge mx-305, multi-stirrer 15 , magnetic bar, $\mathrm{pH}$ meter, blender (Kirin), botol semprot, dan sendok tanduk.

\section{Bahan}

Bahan yang digunakan dalam penelitian ini adalah ekstrak kulit buah manggis (Garcinia mangostana L.), $\mathrm{AgNO}_{3}$ (Merck, 99,8\%), asam $p$ kumarat (Merck, 99\%), metanol, melamin, dan akuabides.

\section{Prosedur Kerja}

Sintesis nanopartikel perak dilakukan dengan menambahkan sebanyak $1 \mathrm{~mL}$ ekstrak kulit buah manggis (sampel) $0,015 \mathrm{~g} / \mathrm{mL}$ ke dalam $4 \mathrm{~mL}$ larutan $\mathrm{AgNO}_{3} 1 \mathrm{mM}$ dan diaduk dengan magnetik stirrer selama 30 menit pada suhu ruang. Modifikasi AgNP dilakukan dengan menambahkan $1 \mathrm{~mL}$ larutan asam $p$-kumarat 1 $\mathrm{mM}$ ke dalam campuran $\mathrm{AgNO}_{3}$ dan ekstrak sampel setelah waktu pengadukan tercapai dan pengadukan dilanjutkan selama 2 jam berikutnya.

Analisis UV-Vis terhadap koloid AgNP dilakukan pada suhu ruang menggunakan 
spektrofotometer UV-2600 (Shimadzu) pada resolusi $0,5 \mathrm{~nm}$. Ekstrak sebelum dan larutan hasil setelah reaksi dikeringkan pada suhu $60{ }^{\circ} \mathrm{C}$, dan biomassa kering dianalisis menggunakan spektrofotometer FTIR (IRPrestige-21). Koloid AgNP hasil sintesis disentrifuse pada kecepatan $10.000 \mathrm{rpm}$ selama 30 menit. Hasil sentrifuse berupa padatan dikumpulkan dan dikeringkan pada suhu $60{ }^{\circ} \mathrm{C}$ untuk analisis XRD. Analisis XRD dilakukan menggunakan difraktometer XRD Rigaku MiniFlex pada arus $40 \mathrm{~mA}$ dan beda potensial $45 \mathrm{kV}$ dengan radiasi $\mathrm{CuK} \alpha$ untuk mengonfirmasi bentuk kristal nanopartikel perak.

Analisis melamin dilakukan dengan menambahkan koloid APK-AgNP pada masingmasing larutan melamin konsentrasi $0,1,1,10$, 100, dan 1000 ppm. Selanjutnya, masing-masing campuran diukur serapannya dengan spektrofotometer UV-Vis pada panjang gelombang 200-800 $\mathrm{nm}$.

\section{HASIL DAN PEMBAHASAN}

\section{Sintesis Nanopartikel Perak}

Pertumbuhan Nanopartikel perak (AgNP) diamati menggunakan spektrofotometer UV-Vis berdasarkan pita serapan Surface Plasmon Resonance (SPR). Surface Plasmon resonance (SPR) merupakan kumpulan osilasi terhadap elektron konduksi. SPR adalah polarisasi muatan permukaan yang dihasilkan dari kumpulan osilasi electron atau analog untuk kumpulan osilasi elektron dengan gas plasma. Ketika suatu material berinteraksi dengan cahaya (gelombang elektromagnetik) maka akan tercipta osilasi pada permukaan material (Wiley dkk., 2006).

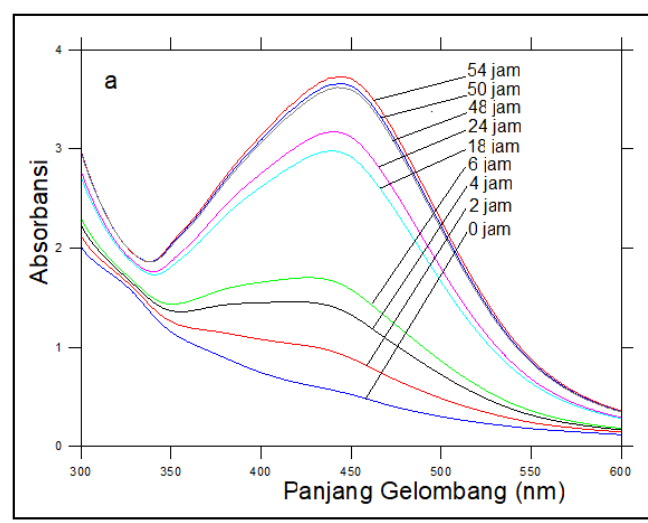

UV-Vis AgNP sebagai fungsi waktu reaksi yang dihasilkan oleh larutan $\mathrm{AgNO}_{3} 1 \mathrm{mM}$ dengan ekstrak sampel $0,015 \mathrm{~g} / \mathrm{mL}$ pada suhu $30^{\circ} \mathrm{C}$.

Pada Gambar 1, menunjukkan perubahan pola intesitas serapan SPR selama waktu reaksi dengan munculnya puncak SPR pada pengukuran ke-4 jam setelah penambahan larutan ekstrak ke dalam larutan $\mathrm{AgNO}_{3} 1 \mathrm{mM}$. Puncak SPR yang khas sekitar 443,5 nm sesuai untuk karakter SPR AgNP (Irwan dkk., 2016, Zakir dkk., 2014). Nilai SPR ini relatif sama seperti yang dilaporkan Rajakannu, dkk. (2015) yang menunjukkan nilai serapan SPR AgNP pada $430 \mathrm{~nm}$ yang disintesis menggunakan ekstrak buah manggis. Adanya kumpulan oskilasi elektron pada permukaan logam menyebabkan eksitasi getaran Plasmon permukaan nanopartikel perak sehingga pita serapan SPR akan muncul pada daerah sekitar 430 $\mathrm{nm}$ yang berhubungan dengan frekuensi getaran Plasmon (Willets, 2007). Kumpulan oskilasi elektron dapat diamati dari perubahan warna larutan dari kuning menjadi coklat gelap mengindikasikan adanya sebaran partikel dalam larutan.

Stabilitas nanopartikel dapat diketahui dari pita serapan SPR (Huang dkk., 2011b). Untuk memonitor kestabilan koloid perak, spektra serapan koloid diukur berdasarkan perbedaan waktu inkubasi. Adanya pola intensitas serapan yang secara berangsur-angsur meningkat mengindikasi kestabilan AgNP. Meningkatnya puncak SPR selama waktu inkubasi mengindikasikan kerapatan nanopartikel dalam larutan (Ahmad dkk., 2013).

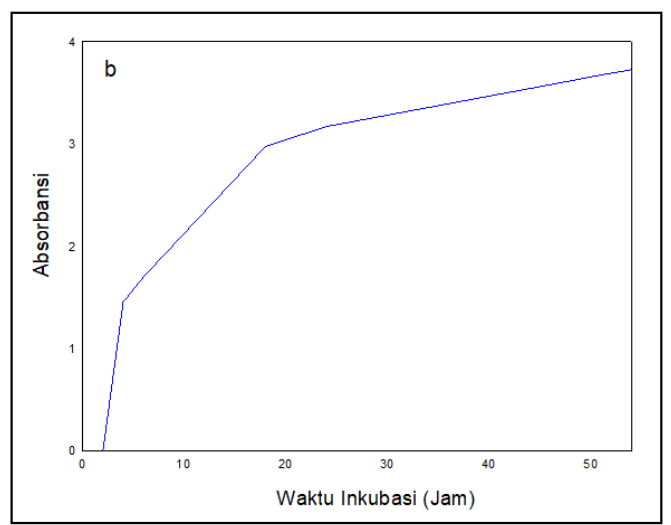

Gambar 1. (a) Spektra UV-Vis AgNP selama waktu reaksi, (b) Perubahan intensitas serapan SPR selama waktu reaksi

Spektroskopi UV-Vis dapat digunakan untuk mengamati pertumbuhan nanopartikel perak. Gambar 1 menunjukkan spektra serapan

\section{Analisis Gugus Fungsi menggunakan FTIR}

Berdasarkan nilai SPR AgNP, suspensi nanopartikel diindikasikan stabil selama waktu 
inkubasi yang menunjukkan AgNP distabilkan dalam larutan dengan biomolekul yang terdapat dalam ekstrak. Pengukuran FTIR dilakukan untuk mengidentifikasi kemungkinan gugus fungsi dalam ekstrak. Ekstrak kulit buah manggis digunakan bukan hanya sebagai pengstabil tetapi juga mereduksi ion $\mathrm{Ag}^{+}$pada pembentukan nanopartikel (Tikirik dkk., 2015). melalui reduksi $\mathrm{AgNO}_{3} 1 \mathrm{mM}$ menggunakan ekstrak kulit buah manggis $0.015 \mathrm{~g} / \mathrm{mL}$ pada suhu $30{ }^{\circ} \mathrm{C}$ mengonfirmasi adanya nanopartikel perak (Gambar 3). Puncak difraksi pada sudut $2 \theta$ $37,79^{\circ}, 43,97^{\circ}, 64,25^{\circ}$, dan $77,28^{\circ}$ masingmasing sesuai dengan bidang (111), (200), (202), dan (311). Pola difraksi dengan Indeks Miller (111) sesuai dengan sistem kristal kubik AgNP

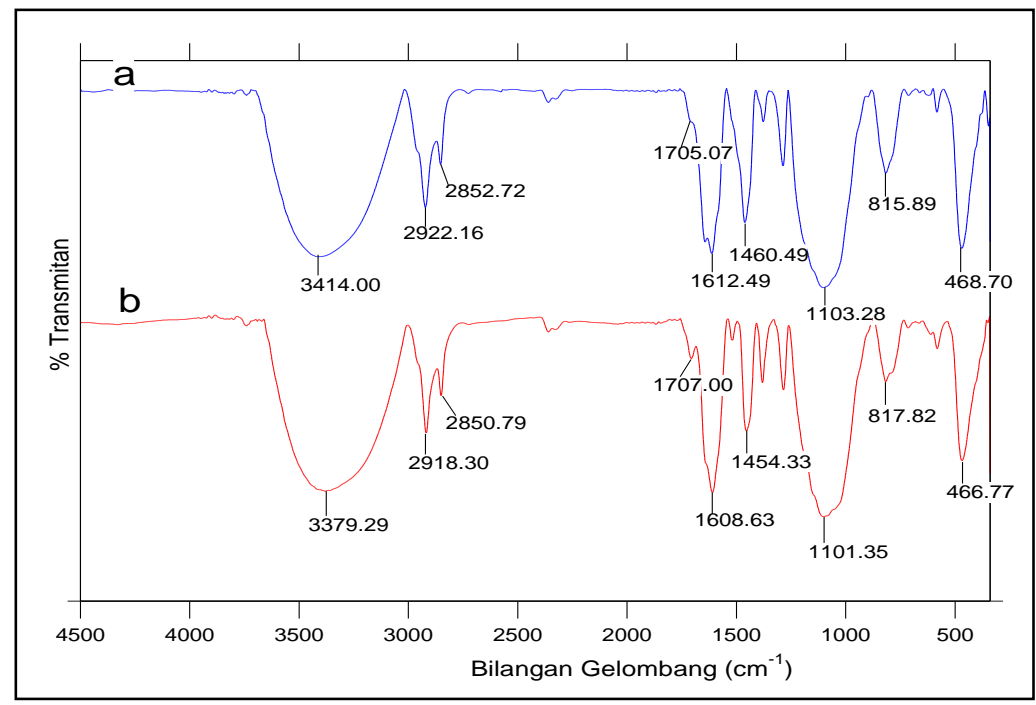

Gambar 2. (a) Spektrum IR ekstrak sampel, dan (b) AgNP

Gambar 2b menunjukkan spektrum serapan IR AgNP. Puncak serapan yang muncul pada $3379 \mathrm{~cm}^{-1}$ dapat disebabkan oleh vibrasi ulur gugus $-\mathrm{OH}$. Puncak yang muncul pada $2918 \mathrm{~cm}^{-1}$ disebabkan oleh vibrasi ulur- $\mathrm{CH}$. Puncak tajam yang diamati pada $1608 \mathrm{~cm}^{-1}$ dan puncak yang sedikit lemah pada $1707 \mathrm{~cm}^{-1}$ masing-masing disebabkan oleh vibrasi ulur $\mathrm{C}=\mathrm{C}$ aromatik dan $\mathrm{C}=\mathrm{O}$. Pergeseran bilangan gelombang terjadi pada vibrasi ulur $-\mathrm{OH}$ dari $3414 \mathrm{~cm}^{-1}$ pada ekstrak sampel (Gambar 2a) menjadi $3379 \mathrm{~cm}^{-1}$ pada AgNP (Gambar 2b) dan meningkatnya intensitas serapan vibrasi ulur $-\mathrm{C}=\mathrm{O}$ pada hasil sintesis (1705 menjadi $1707 \mathrm{~cm}^{-1}$ ) memberikan indikasi oksidasi gugus $-\mathrm{OH}$ menjadi gugus $-\mathrm{C}=\mathrm{O}$. Ion $\mathrm{Ag}^{+}$akan direduksi secara bersamaan menjadi nanopartikel perak. Adanya oksidasi gugus $-\mathrm{OH}$ menjadi karbonil $-\mathrm{C}=\mathrm{O}$ dikonfirmasi dari $\mathrm{pH}$ larutan yang menurun selama waktu inkubasi dari pH 8,2 menjadi 5,5 mengindikasi lepasnya ion $\mathrm{H}^{+}$ di dalam larutan.

\section{Analisis menggunakan XRD}

Untuk mengonfirmasi struktur AgNP dilakukan analisis pola $X$-ray diffraction (XRD). Karakteristik puncak yang diamati pada pola XRD terhadap nanopartikel yang dihasilkan
(Zakir dkk., 2014). Puncak yang relatif tajam pada pola XRD (111) mengindikasi fasa kristalnya AgNP. Perkiraan ukuran partikel perak dapat dihitung dari persamaan Debye-Scherer (Ahmad dkk., 2010) dengan menentukan lebar terhadap indeks refleksi Bragg (111). Berdasarkan perhitungan menggunakan persamaan tersebut diperoleh estimasi ukuran partikel sebesar 30.36 nm (Gambar 3).

\section{Stabilitas AgNP dengan asam $p$-kumarat}

Modifikasi AgNP dilakukan dengan menggunakan larutan asam $p$-kumarat (APK). Pemilihan senyawa APK didasarkan pada gugus fungsi karbonil, hidroksil, dan hidroksi fenol yang berpotensi berinteraksi dengan AgNP dan melamin. Larutan APK $1 \mathrm{mM}$ dengan volume 1 mL ditambahkan ke dalam larutan AgNP hasil sintesis dengan waktu pengadukan selama 2 jam (Song dkk., 2014). Pengukuran nilai SPR dilakukan setelah waktu ke-54 jam untuk memonitor pertumbuhan AgNP berdasarkan modifikasi dengan APK. Perbandingan nilai serapan SPR AgNP dan APK-AgNP menunjukkan adanya penurunan intesitas serapan dari $3.729, \lambda=443 \mathrm{~nm}$ menjadi $2.320, \lambda=446 \mathrm{~nm}$ (Gambar 4). Adanya senyawa APK yang berperan 
sebagai ligan menyebabkan terjadi penurunan intesitas serapan SPR sebelum dan setelah modifikasi (Ma dkk., 2011). ulur $\mathrm{C}-\mathrm{H}$ alifatik dan $=\mathrm{C}-\mathrm{H}$ aromatik. Pita serapan pada 1672-1598 $\mathrm{cm}^{-1}$ dapat disebabkan oleh vibrasi ulur $\mathrm{C}=\mathrm{C}$ aromatik dan alkena. Pita serapan pada $1247-1107 \mathrm{~cm}^{-1}$ dan $975-688 \mathrm{~cm}^{-1}$

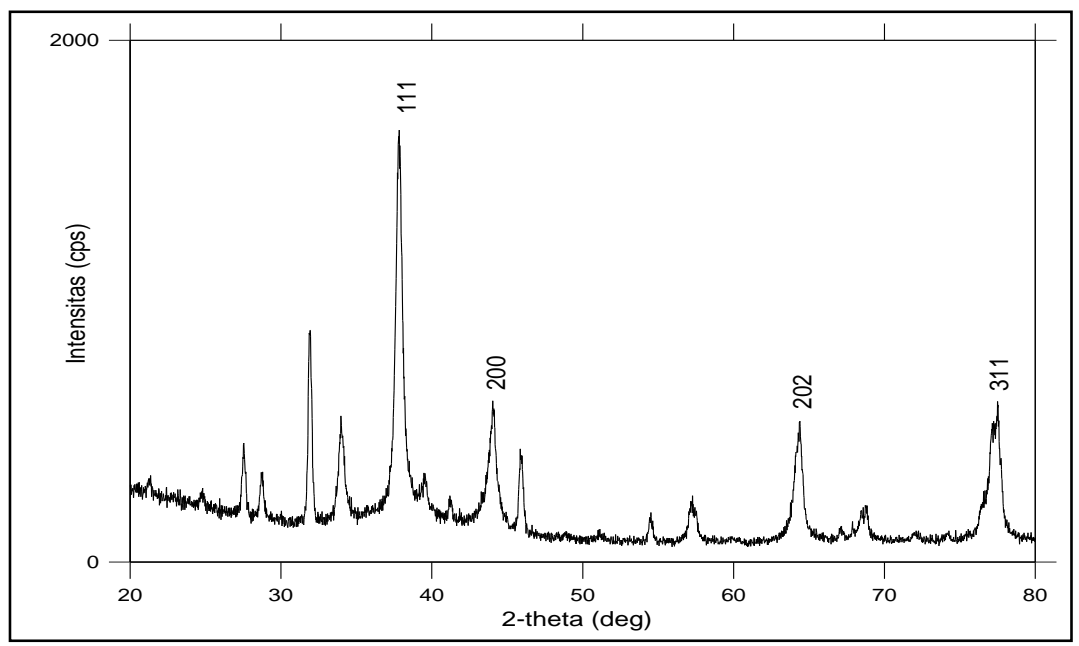

Gambar 3. Pola XRD AgNP

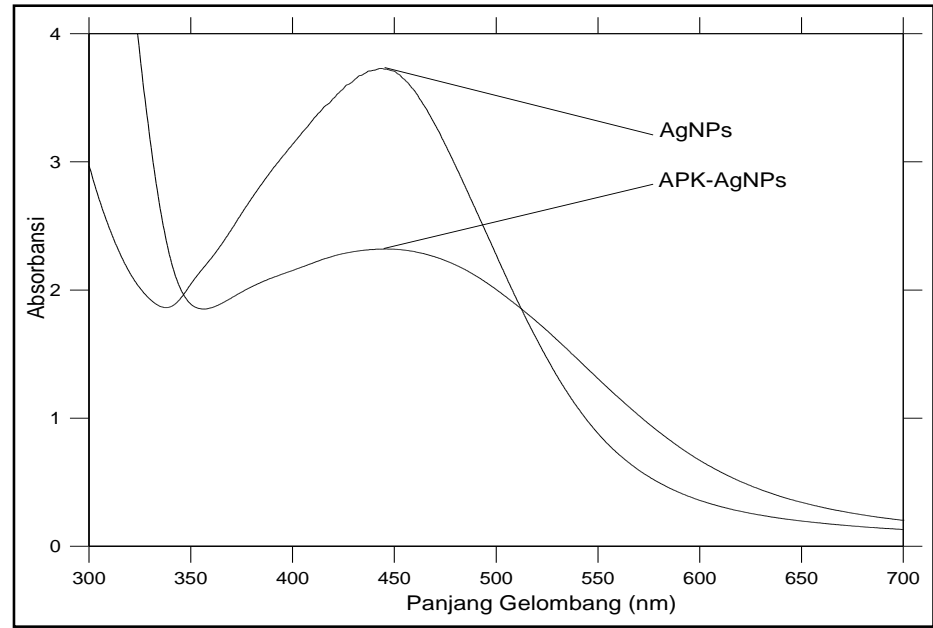

Gambar 4. Pola SPR AgNP dan APK-AgNP

Koloid APK-AgNP dikeringkan selama 12 jam. Hasil pengeringan berupa endapan APKAgNP dianalisis menggunakan spektrofotometer FTIR dengan pelet $\mathrm{KBr}$ pada bilangan gelombang 4000-250 $\mathrm{cm}^{-1}$. Spektrum IR APK-AgNP juga dibandingkan dengan hasil spektrum IR AgNP hasil sintesis.

Identifikasi interaksi yang mungkin antara APK dan AgNP dilakukan dengan analisis terhadap spektrum IR modifikasi APK-AgNP (Gambar 5a) dan dibandingkan dengan APK murni (Gambar 5b). Perbandingan ini dilakukan untuk mengidentifikasi gugus pada APK yang berinteraksi langsung dengan AgNP. Spektrum IR APK murni menunjukkan pita serapan pada daerah $3070-2501 \mathrm{~cm}^{-1}$ yang merupakan vibrasi masing-masing dapat disebabkan oleh vibrasi ulur $\mathrm{C}-\mathrm{O}$ karboksilat dan tekuk $\mathrm{C}-\mathrm{H}$ dalam-luar bidang.

Untuk mempelajari interaksi senyawa APK pada permukaan AgNP, dilakukan pengukuran serapan IR pada molekul APK dan koloid APKAgNP. Pita serapan pada $3381 \mathrm{~cm}^{-1}$ disebabkan oleh vibrasi ulur $\mathrm{O}-\mathrm{H}$ fenol dan $\mathrm{O}-\mathrm{H}$ karboksilat. Pita serapan pada $1508 \mathrm{~cm}^{-1}$ dan $1774 \mathrm{~cm}^{-1}$ kemungkinan disebabkan vibrasi ulur $\mathrm{C}=\mathrm{O}$ karboksilat. Spektrum IR APK-AgNP dibandingkan dengan spektrum APK murni dan AgNP tanpa modifikasi (Gambar 2b) untuk mengetahui sisi interaksi antara APK dan AgNP. 
Irwan R. dkk. / Indo. J. Chem. Res., 2020, 7(2), 141 - 150
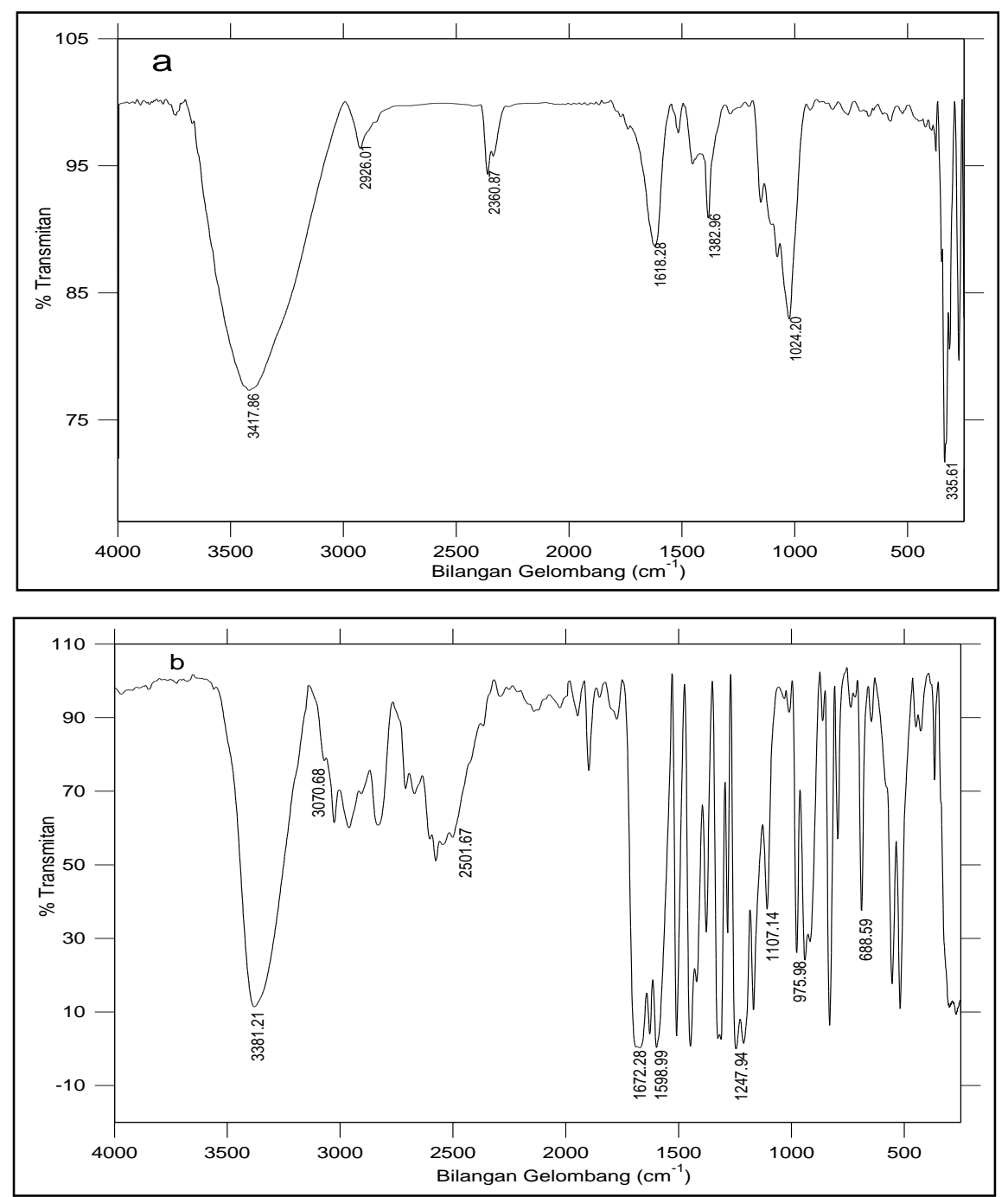

Gambar 5. (a) Spektrum IR APK-AgNP, dan (b) Asam p-kumatat (APK) murni

Spektrum IR APK-AgNP (Gambar 5a) menunjukkan pita serapan pada daerah 30702501, 1672-1598, 1247-1107, dan 975-688 $\mathrm{cm}^{-1}$ cenderung menghilang. Hal ini mengindikasi bahwa APK berinteraksi pada permukaan AgNP melalui gugus $\mathrm{C}=\mathrm{C}$ alkena dan aromatik, $=\mathrm{C}-\mathrm{H}$ aromatik, $\mathrm{C}-\mathrm{H}$ alifatik, $\mathrm{C}-\mathrm{O}$ dan $\mathrm{C}=\mathrm{O}$ karboksilat.

Spektrum serapan IR APK pada daerah 3381 $\mathrm{cm}^{-1}$ muncul pada daerah $3417 \mathrm{~cm}^{-1}$ spektrum IR APK-AgNP dengan intensitas yang relatif tidak berubah. Hal ini mengindikasi kemungkinan tidak adanya interaksi pada gugus $-\mathrm{OH}$ fenol antara APK dengan AgNP. Interaksi ini dapat dijelaskan berdasarkan prinsip teori asam basa keras lunak oleh Pearson (1968) yang mengklasifikasi asam dan basa ke dalam 3 kategori, keras, lunak, dan borderline.
Kecenderungan interaksi yang terjadi adalah asam keras dengan basa keras dan asam lemah dengan basa lemah. Berdasarkan teori Pearson, maka AgNP yang merupakan hasil reduksi $\mathrm{Ag}^{+}$ diasumsikan sebagai basa lemah yang akan berinteraksi dengan $\mathrm{C}_{6} \mathrm{H}_{6}, \mathrm{C}=\mathrm{O}$ dan $\mathrm{C}-\mathrm{O}$ yang bersifat basa lemah (Pearson, 1968) pada APK. Interaksi ini menginduksi perubahan spektrum pada daerah serapan masing-masing gugus fungsi tersebut (Gambar 5). Hal ini dikuatkan oleh spektrum IR AgNP (Gambar 2b) dimana spektrum yang mencolok pada bilangan gelombang 2918-2850, 1608, 1101, dan $817 \mathrm{~cm}^{-1}$ yang identik dengan vibrasi ulur $\mathrm{C}-\mathrm{H}, \mathrm{C}=\mathrm{C}$ aromatik, C-O-C eter dan $=\mathrm{C}-\mathrm{H}$ mengalami penurunan intensitas pada hasil modifikasi dengan APK (Gambar 5a). intensitas serapan pada daerah $3379 \mathrm{~cm}^{-1}$ yang relatif tidak berubah 
pada spektrum AgNP mengindikasi tidak adanya pengikatan antara gugus $-\mathrm{OH}$ fenol dengan gugus pada APK.
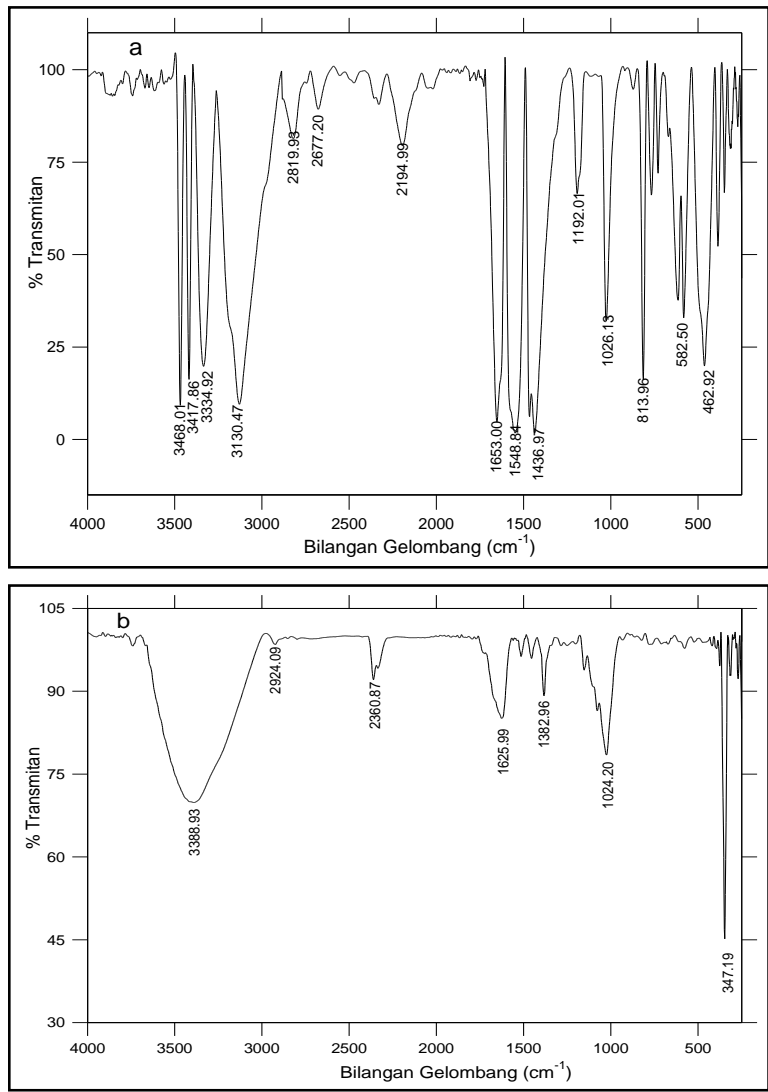

Gambar 6. (a) Spektrum IR melamin murni, dan (b) APK-AgNP+melamin
Aplikasi APK-AgNP dalam mendeteksi melamin

Interaksi cahaya dengan nanopartikel logam memberikan suatu hal yang menarik. Salah satu aplikasi dari interaksi ini digunakan untuk aplikasi deteksi secara kimia dan biologi. Prinsip deteksi ini didasarkan pada cahaya yang dilokasilasi, dimanipulasi dan dikuatkan dalam skala nanometer melalui eksitasi kumpulan oskilasi elektron dalam nanopartikel logam yang dikenal dengan localized surface Plasmon resonance (LSPR).

APK-AgNP diuji terhadap deteksi melamin melalui penambahan melamin ke dalam koloid APK-AgNP dan mengamati puncak serapan terhadap perubahan warna sistem (Wu dkk., 2011). Melamin dengan konsentrasi 0,$1 ; 1 ; 10$; 100; 1000 ppm, masing-masing ditambahkan ke dalam APK-AgNP dan diukur dengan spektrofotometer UV-Vis pada daerah $\lambda$ 300-800 $\mathrm{nm}$. Pendeteksian melamin ditandai dengan menurunnya serapan SPR terhadap APK-AgNP setelah ditambahkan melamin berbagai konsentrasi yang ditandai dengan perubahan warna dari kuning muda menjadi kuning kecoklatan (Gambar 8). Hal ini dapat disebabkan oleh agregasi yang terjadi pada nanopartikel setelah ditambahkan suatu analit seperti melamin (Ma dkk., 2011, Shang dkk., 2013, Song dkk., 2014).

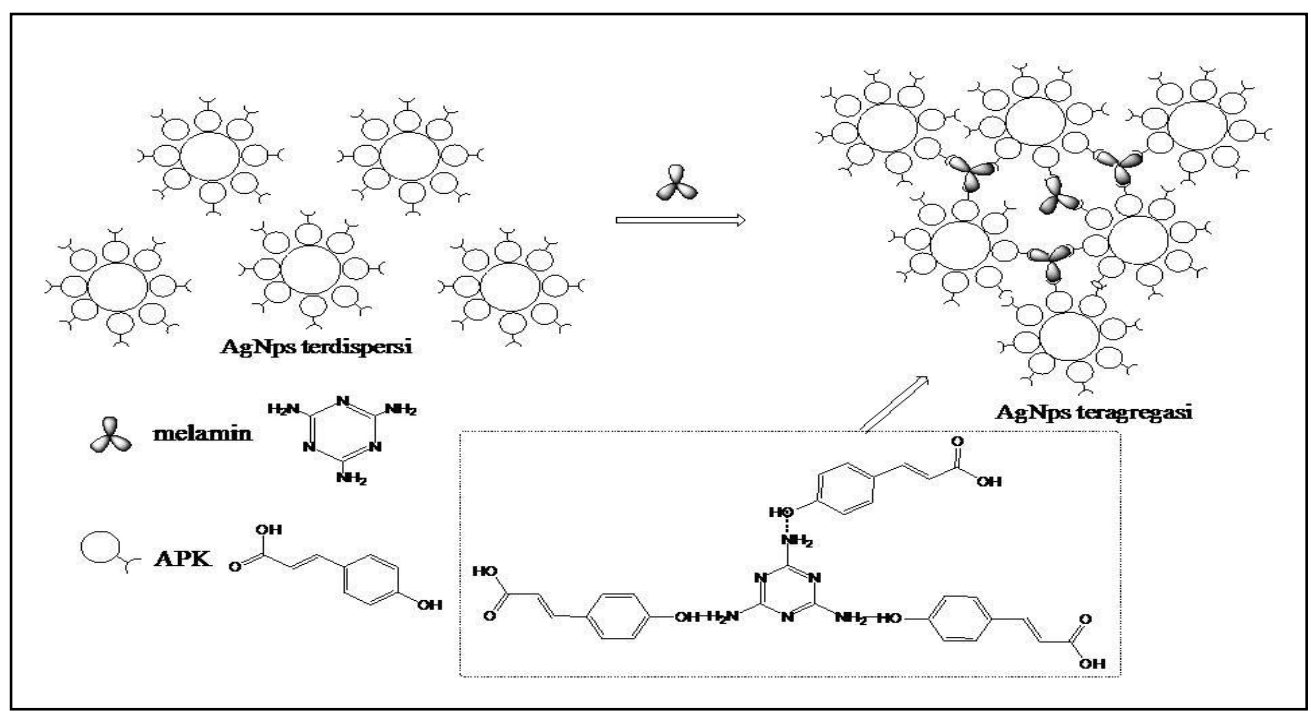

Gambar 7. Mekanisme interaksi yang mungkin antara APK-AgNPs dan melamin 
Interaksi nanopartikel perak dengan $\mathrm{m}$ elamin selanjutnya diuji menggunakan spektrofotometer FTIR. Puncak serapan IR melamin murni (Gambar 6a) memperlihatkan serapan yang tajam pada daerah 3130, 3334, 3417 , dan $3468 \mathrm{~cm}^{-1}$ yang dapat disebabkan oleh vibrasi ulur $-\mathrm{N}-\mathrm{H}$ amina. Puncak serapan pada 1653 dan $1548 \mathrm{~cm}^{-1}$ dapat disebabkan oleh vibrasi $\mathrm{C}=\mathrm{N}$ aromatik.

Puncak serapan pada 729, 767, dan $813 \mathrm{~cm}^{-1}$ dapat disebabkan oleh vibrasi $-\mathrm{NH}_{2}$ tekuk. Puncak serapan pada daerah 1436 dan $1465 \mathrm{~cm}^{-1}$ dapat disebabkan oleh kombinasi C-N aromatik. Puncak serapan pada 1026 dan $1192 \mathrm{~cm}^{-1}$ disebabkan oleh C-N ulur alifatik. Pita serapan yang muncul di daerah 615-426 $\mathrm{cm}^{-1}$ kemungkinan disebabkan oleh senyawa yang mengandung halogen dari pelet $\mathrm{KBr}$ (Stuart, 2004). Perubahan bentuk serapan yang tajam terjadi pada daerah $3468-3130 \mathrm{~cm}^{-1}$ pada melamin murni setelah dikontakkan dengan APK-AgNP (Gambar 6b) mengindikasi adanya interaksi gugus $-\mathrm{NH}_{2}$ dengan APK-AgNP.

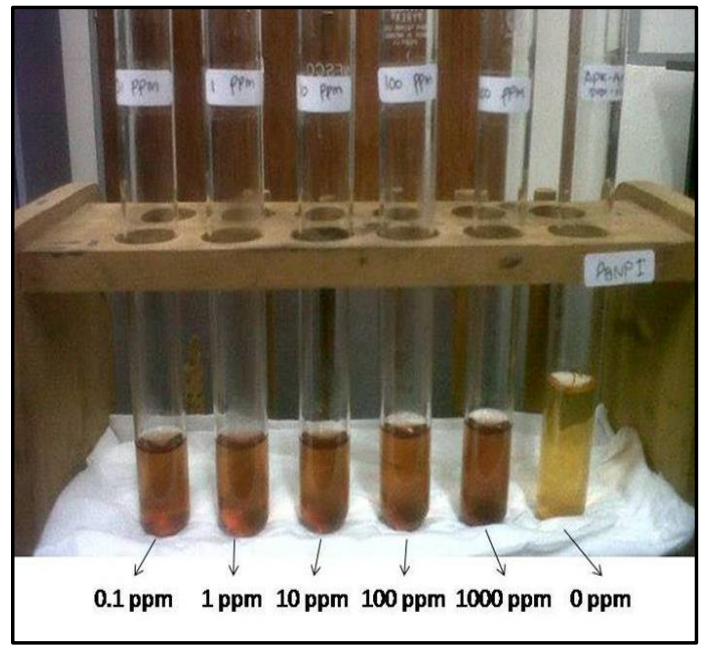

Gambar 8. Perubahan Warna AgNP (kuning muda menjadi kuning kecoklatan) setelah ditambahkan melamin berbagai konsentrasi

Interaksi juga terjadi pada gugus $\mathrm{C}=\mathrm{N}$ aromatik, $\mathrm{C}-\mathrm{N}$ aromatik dan $\mathrm{C}-\mathrm{N}$ alifatik yang ditandai dengan berkurangnya intensitas serapan pada masing-masing daerah tersebut. Pergeseran bilangan gelombang serapan IR yang mencolok terjadi pada daerah $3417,86 \mathrm{~cm}^{-1}$ pada APKAgNP (Gambar 5a) setelah ditambahkan melamin menjadi 3388,93 $\mathrm{cm}^{-1}$ (Gambar 6b) dengan sedikit penurunan intensitas. Adanya pergeseran dan penurunan intensitas serapan tersebut dapat disebabkan oleh kemungkinan interaksi melamin dengan gugus $-\mathrm{OH}$ yang terdapat pada nanopartikel hasil modifikasi (APK-AgNP).

Adanya ikatan hidrogen di dalam molekul menyebabkan bergesernya pita serapan ke angka bilangan gelombang yang lebih rendah (Sastrohamidjojo, 1985). Berdasarkan data hasil spektrum IR maka dapat dibuat suatu ilustrasi skematis terhadap mekanisme yang mungkin untuk deteksi melamin didasarkan pada APK$\operatorname{AgNP}$ (Gambar 7).

\section{KESIMPULAN}

Nanopartikel perak dapat disintesis menggunakan ekstrak kulit buah manggis dan dapat dimodifikasi dengan asam $p$-kumarat. Waktu inkubasi berpengaruh terhadap hasil sintesis nanopartikel perak. Ukuran nanopartikel perak yang dihasilkan berdasarkan estimasi perhitungan dengan persamaan Debye-Scherer adalah 30,36 nm dengan bentuk kubik. Serapan SPR nanopartikel perak berada pada daerah 443,5 $\mathrm{nm}$, dan gugus $-\mathrm{OH}$ bertanggungjawab terhadap reduksi $\mathrm{AgNO}_{3}$ menjadi nanopartikel perak. Nanopartikel perak hasil modifikasi memiliki pengaruh terhadap melamin konsentrasi 0,1-1000 ppm.

\section{DAFTAR PUSTAKA}

Ahmad, N., Sharma, S., Alam, Md. K., Singh, V. N., Shamsi, S. F., Mehta, B. R., Fatma, A., 2010, Rapid Synthesis of Silver Nanoparticle using Dried Medicinal Plant of Basil, Colloids Surf., B, Biointerfaces, 81, 81-86.

Ahmad, T., Wani, I. A., Manzoor, N., Ahmed, J., Asiri, A. M., 2013, Biosynthesis, Structural Characterization and Antimicrobial Activity of Gold and Silver Nanoparticles, Colloids Surf., B, Biointerfaces, 107, 227-234.

Chaverri, J. P., Rodriguez, N. C., Ibarra, M. O., Rojas, J. M. P., 2008, Medical Properties of Mangosteen (Garcinia mangostana), Food Chem., Toxi., 46, 3227-3239.

Chen, N., Cheng, Y., Li, C., Zhang, C., Zhao, K., Xian, Y., 2015, Determination of Melamine in Food Contact Materials using an Electrode Modified with Gold Nanoparticles and Reduced Graphene Oxide, Microchim., Acta, 182, 1967-1975.

Gaspersz, N., Sohilait, M. R., 2019, Penambatan Molekuler $\alpha, \beta$, dan $\gamma$-Mangostin Sebagai Inhibitor $\alpha$-Amilase Pankreas Manusia, Indo. J. Chem. Res., 6(2), 59-66. 
Han, C.P., Li, H. B., 2010, Visual Detection of Melamine in Infant Formula at $0,1 \mathrm{ppm}$ Level Based on Silver Nanoparticles, Analyst., 135, 583-588.

Huang, H., Li, L., Zhou, G., Liu, Z., Feng, Y., Zeng, G., Tinnefeld, P., Ma, Q., He, Z., 2011a, Visual detection of melamine in milk samples based on label-free and labeled gold nanoparticles, Talanta, 85, 1013-1019.

Huang, J., Zhan, G., Zheng, B., Sun, D., Lu, F., Lin, Y., Chen, H., Zheng, Z., Zheng, Y., Li, Q., 2011b, Biogenic Silver Nanoparticles by Cacumen platycladi Extract: Synthesis, Formation Mechanism, and Antibacterial Activity, Ind, Eng, Chem. Res., 50, 90959106.

Irwan, R., Zakir, M., Budi, P., 2016, Effect of $\mathrm{AgNO}_{3}$ Concentration and Synthesis Temperature on Surface Plasmon Resonance (SPR) of Silver Nanoparticles, Ind. J. Chem. Res., 4(1), 356-361.

Jean, R. D., Chiu, K. C., Chen, T. H., Chen, C. H., Liu, D. M., 2010, Functionalized Silica Nanoparticles by Nanometallic Ag Decoration for Optical Sensing of Organik Molecule, J. Phys. Chem. C., 114, 1563315639.

Kuang, H., Chen, W., Yan, W. J., Xu, L. G., Zhu, Y. Y., Liu, L. Q., Chu, H. Q., Peng, C. F., Wang, L. B., Kotov, N. A., Xu, C. L., 2011, Crown Ether Assembly of Gold Nanoparticles: Melamine Sensor, Biosens. Bioelectron, 26, 2032-2037.

Liang, X., Wei, H., Cui, Z., Deng, J., Zhang, Z., You, X., Zhang, X. E., 2011, Colorimetric Detection of Melamine in Complex Matrices Based on Cysteamine-Modified Gold Nanoparticles, Analyst., 136, 179-183.

Ma, Y. R., Niu, H. Y., Zhang, X. L., Cai, Y. Q., 2011, One-step Synthesis of Silver/dopamine Nanoparticles and Visual Detection of Melamine in Raw Milk, Analyst., 136, 4192-4196.

Mittal, A. K., Bhaumik, J., Kumar, S., Banerjee, U. C., 2014, Biosynthesis of Silver Nanoparticle: Elucidation of Prospective Mechanism and Therapeutic Potential, $J$. Colloid Interface Sci, 415, 39-47.

Nayak, D., Ashe, S., Rauta, P. R., Kumari, M., Nayak, B., 2016, Bark Extract Mediated Green Synthesis of Silver Nanoparticles: Evaluation of Antimicrobial Activity and Antiproliferative Response, Mater. Sci. Eng, C, 58, 44-52.
Niraimathi, K. L., Sudha, V., Lavanya, R., Brindha, P., 2012, Biosynthesis of Silver Nanoparticles using Alternanthera sessilis (Linn.) Extract and their Antimicrobial, Antioxidant Activities, Colloids Surf., B, 102, 288-291.

Pearson, R. G., 1968, Hard and Soft Acids and Bases, HSAB, Part 1 Fundamental Principles, J. Chem. Edu, 45(9), 581-587.

Ping, H., Zhang, M. W., Li, H. K., Li, S. G., Chen, Q. S., Sun, C. Y., Zhang, T. H., 2012, Visual Detection of Melamine in Raw Milk by Label-free Silver Nanoparticles, Food Control, 23, 191-197.

Qiao, G., Guo, T., Klein, K. K., 2010, Melamine in Chinese Milk Products and Consumer Confidence, Appetite, 55, 190-195.

Rajakannu, S., Shankar, S., Perumal, S., Subramanian, S., Dhakshinamoorthy, G. P., 2015, Biosynthesis of Silver Nanoparticles using Garcinia mangostana Fruit Extract and their Antibacterial, Antioxidant Activity, Int. J. Curr. Microbiol. App. Sci, 4(1), 944952.

Shang, Y., Gao, D., Wu, F., Wan, X., 2013, Silver Nanoparticle Capped with 8hydroxyquinoline-5-sulfonate for the Determination of Trace Aluminium in Water Samples and for Intracellular Fluorescence Imaging, Microchim. Acta, 180, 1317-1324.

Song, J., Wu, F., Wan, Y., Ma, L. H., 2014, Visual Test for Melamine using Silver Nanoparticles Modified with Chromotropic Acid, Microchim. Acta, 181, 1267-1274.

Squadrone, S., Ferro, G. L., Marchis, D., Mauro, C., Palmegiano, P., Amato, G., Genin, E. P., Abete, M. C., 2010, Determination of Melamine in Feed: Validation of a Gas Chromatography-mass Spectrometry Method According to 2004/882/CE Regulation, Food Control, 21, 714-718.

Stuart, B., 2004, Infrared Spectroscopy: Fundamentals and Applications, John Wiley $\&$ Sons, Ltd.

Taba, P., Parmitha, N. Y., Kasim, S., 2019, Sintesis Nanopartikel Perak Menggunakan Ekstrak Daun Salam (Syzygium polyanthum) Sebagai Bioreduktor dan Uji Aktivitasnya Sebagai Antioksidan, Indo. J. Chem. Res., 7(1), 51-60.

Tikirik, W. O., Maming, Zakir, M., 2015, Sintesis Nanopartikel Perak menggunakan Bioreduktor dari Ekstrak Kulit Buah Manggis (Garcinia mangostana L.) sebagai 
Irwan R. dkk. / Indo. J. Chem. Res., 2020, 7(2), 141 - 150

Indikator Kolorimetri keberadaan Logam $\mathrm{Hg}^{2+}$. Repository.unhas.ac.id.

Venkatasami, G., Sowa, J. R. Jr., 2010, A Rapid, Acetonitrile-free, HPLC Method for Determination of Melamine in Infant Formula, Anal. Chim. Acta, 665, 227-230.

Wiley, B. J., Im, S. H., Li, Z. Y., McLellan, J., Siekkinen, A., Xia, Y., 2006, Maneuvering the Surface Plasmon Resonance of Silver Nanostructure through Shape-Controlled Synthesis, J. Phys. Chem. B., 110, 1566615675.

Willets, K. A., Hall, W. P., Sherry, L. J., Zhang, X., Zhao, J., Duyne, R. P. V., 2007, Nanoscsale Localized Surface Plasmon Resonance Biosensors, Nanobiotech. II, 159173.
Wu, Z., Zhao, H., Xue, Y., Cao, Q., Yang, J., He, Y., Li, X., Yuan, Z., 2011, Colorimetric Detection of Melamine during the Formation of Gold Nanoparticles, Biosens. Bioelectron, 26, 2574-2578.

Yousefzadi, M., Rahimi, Z., Ghafori, V., 2014, The Green Synthesis, Characterization and Antimicrobial Activities of Silver Nanoparticles Synthesized from Green Alga Enteromorpha flexuosa (wulfen) J. Agardh, Mater. Lett., 137, 1-4.

Zakir, M., Maming, Lembang, E. Y., Lembang, M. S., 2014, Synthesis of Silver and Gold Nanoparticles through Reduction Method using Bioreductor of Leaf Extract of Ketapang (Terminalia catappa), Int. Con. Adv. Mater. \& Prac. Nanotech, Jakarta. 